\title{
Application of environmental isotopes and hydrochemistry in the identification of source of seepage and likely connection with lake water in Lesser Himalaya, Uttarakhand, India
}

\author{
Shive Prakash Rai ${ }^{1}$, Dharmaveer Singh ${ }^{1, *}$ (i), Ashwani Kumar Rai ${ }^{2}$ \\ and BHISHM KUMAR ${ }^{3}$ \\ ${ }^{1}$ Hydrological Investigation Division, National Institute of Hydrology, Roorkee 247 667, India. \\ ${ }^{2}$ School of Biotechnology, Gautam Buddha University, Gautam Budh Nagar, Greater Noida 201308 , India. \\ ${ }^{3}$ Isotope Hydrology Section, International Atomic Energy, P.O. Box 100, A-1400 Vienna, Austria. \\ *Corresponding author. e-mail: veermnnit@gmail.com
}

MS received 21 December 2016; revised 18 May 2017; accepted 22 May 2017; published online 24 November 2017

Oxygen $\left(\delta^{18} \mathrm{O}\right)$ and hydrogen $\left(\delta^{2} \mathrm{H}\right.$ and $\left.{ }^{3} \mathrm{H}\right)$ isotopes of water, along with their hydrochemistry, were used to identify the source of a newly emerged seepage water in the downstream of Lake Nainital, located in the Lesser Himalayan region of Uttarakhand, India. A total of 57 samples of water from 19 different sites, in and around the seepage site, were collected. Samples were analysed for chemical tracers like $\mathrm{Ca}^{++}$, $\mathrm{Mg}^{++}, \mathrm{Na}^{+}, \mathrm{K}^{+}, \mathrm{SO}_{4}^{--}$and $\mathrm{Cl}^{-}$using an Ion Chromatograph (Dionex IC-5000). A Dual Inlet Isotope Ratio Mass Spectrometer (DIIRMS) and an Ultra-Low Level Liquid Scintillation Counter (ULLSC), were used in measurements of stable isotopes $\left(\delta^{2} \mathrm{H}\right.$ and $\left.\delta^{18} \mathrm{O}\right)$ and a radioisotope $\left({ }^{3} \mathrm{H}\right)$, respectively. Results obtained in this study repudiate the possibility of any likely connection between seepage water and the lake water, and indicate that the source of seepage water is mainly due to locally recharged groundwater. The study suggests that environmental isotopes $\left(\delta^{2} \mathrm{H}, \delta^{18} \mathrm{O}\right.$ and $\left.{ }^{3} \mathrm{H}\right)$ can effectively be used as 'tracers' in the detection of the source of seepage water in conjunction with other hydrochemical tracers, and can help in water resource management and planning.

Keywords. Environmental isotope; tracers; stable isotopes; radioisotope; lake.

\section{Introduction}

Water has a tendency to flow from a surface water system (lakes, rivers, reservoirs, etc.) to its surrounding groundwater system or vice versa (Saravana Kumar et al. 2008). This can be viewed by examining the phreatic heads of the local groundwater systems in relation to water level of the surface water systems. But, the large variances, in the permeability may cause difficulty in the interpretation of differences in water levels in terms of actual transport of water (Payne 1983). Seepage/leakage of water from the lakes, reservoirs and rivers may occur through the natural geologic formations in which these water bodies lie (Ahmed et al. 2006). The losses may be in the form of a general seepage, usually covering a wide area, or they may be due to specific leakage flow paths. The identification of seepage/leakage around these features requires the study of origin 
and dynamics of groundwater in their vicinity. The techniques used in the detection of seepage/leakage include geological mapping, geophysical methods such as resistivity measurement and extensive bore drilling, chemical methods, and isotopic techniques (Johansson and Dahlin 1996; Rai et al. 2012). Isotopic techniques, among all the available techniques, are unique and have shown significant potential in detection of fissured rock seepage flow (Chen and Dong 2001). Variations in isotopic composition of water bodies occur during a water cycle process due to differences in their forming mechanisms (Yao et al. 2009). Thus, by analysing isotopic composition, the source and age of water can be estimated (Craig 1961; Yao et al. 2000; Song et al. 2006). However, integration of isotopic techniques with hydrochemical techniques is an advantage, as it remarkably reduces the cost and time in obtaining desired information (Ahmed et al. 2006).

An isotope is the atom of an element having the same atomic number but different atomic weight. Hydrogen has three isotopes: ${ }^{1} \mathrm{H},{ }^{2} \mathrm{H}$ (deuterium) and ${ }^{3} \mathrm{H}$ (tritium). Among them, ${ }^{1} \mathrm{H}$ and ${ }^{2} \mathrm{H}$ are stable isotopes, while ${ }^{3} \mathrm{H}$ is a radioactive isotope of hydrogen with a half-life $\left(\mathrm{T}_{1 / 2}\right)$ of 12.32 years (Dincer et al. 1970). Similarly, oxygen has three main stable isotopes namely, ${ }^{16} \mathrm{O},{ }^{17} \mathrm{O}$ and ${ }^{18} \mathrm{O}$. The concentration of the stable isotopes of hydrogen $\left({ }^{1} \mathrm{H}\right.$ and $\left.{ }^{2} \mathrm{H}\right)$ and oxygen $\left({ }^{16} \mathrm{O},{ }^{17} \mathrm{O}\right.$ and $\left.{ }^{18} \mathrm{O}\right)$ varies significantly in natural water depending upon the geographic locations, climatic conditions and types of water source (Rozanski et al. 1993). But, globally, a correlation between the ratio of hydrogen $\left({ }^{2} \mathrm{H} /{ }^{1} \mathrm{H}\right)$ isotope and oxygen $\left({ }^{18} \mathrm{O} /{ }^{16} \mathrm{O}\right)$ isotope of water is established (Craig 1961). For practical reasons, instead of using the isotope ratio $\left(\mathrm{R}={ }^{2} \mathrm{H} /{ }^{1} \mathrm{H}\right.$ or ${ }^{18} \mathrm{O} /{ }^{16} \mathrm{O}$ ) isotopic compositions are commonly expressed by a delta notation $(\delta)$. This is a measure of the relative deviation of isotope ratios of hydrogen and oxygen with a reference standard such as Vienna-Standard Mean Ocean Water (VSMOW) or Standard Mean Ocean Water (SMOW) as described in equation (1) (Gat et al. 1994)

$$
\delta(\%)=\left(R_{x} / R_{s}-1\right) \times 1000
$$

where $R_{x}$ and $R_{s}$ are the ratios in the sample and standard, respectively. This is expressed in unit of parts per thousands $(\%)$. The increase in $\delta$ values represents an enrichment of the heavy isotopic species relative to the standard, whereas a decrease in $\delta$ values indicate their depletion. The symbol ' $\delta{ }^{2} \mathrm{H}$ ' and ' $\delta{ }^{18} \mathrm{O}$ ' is applied to state the respective deviation of hydrogen and oxygen isotope.

The isotope of oxygen and hydrogen $\left({ }^{1} \mathrm{H},{ }^{2} \mathrm{H}\right.$, ${ }^{3} \mathrm{H},{ }^{16} \mathrm{O}$ and $\left.{ }^{18} \mathrm{O}\right)$, essential elements of a hydrogeological system, are conservative in nature (Saravana Kumar et al. 2008). There is no alteration in their concentrations due to rock interaction. Therefore, these are frequently used as tools in studies of various hydrological processes such as identification of sources and zones of groundwater, source of leakage from lake and reservoir, lake/river-aquifer interactions, and to understand the groundwater dynamics (Clark and Fritz 1997; Deshpande et al. 2003; Li et al. 2007; Rai et al. 2012; Deodhar et al. 2014; Adomako et al. 2015). Krabbenhoft et al. (1990) and LaBaugh et al. (1997) used isotopic tracers to study water balance of the lakes in the United States of America. Environmental isotopes were used by Nachiappan et al. (2002) in the water balance study of Lake Nainital in India. Similarly, Bouchez et al. (2016) applied this approach to quantify the total water outflow and respective proportions of evaporation, transpiration and infiltration from the Lake Chad in central Africa. In some cases, artificial isotopic tracers (usually radioactive) are intentionally injected to understand the hydrological processes in a given hydrological system and also to trace the leakage/seepage locations in the reservoir/dam (Saravana Kumar et al. 2008).

Lake Nainital located in the Lesser Himalayan region of Uttarakhand, India serves as a life line for Nainital city because of its importance in attracting tourists, and supplying fresh water for drinking and other domestic uses. Approximately, $40 \%$ of the total water used for drinking and household purpose comes directly from the lake (Singh et al. 2001). In June 2012, a new source of seepage has emerged out near an outlet of Lake Nainital after a landslide triggered by heavy rainfall event took place. The significant decline in the lake water level was reported by the authority during this period of the year. There is a concern among the local people and authorities over the source of this new seepage point and it is likely connected to the lake's declining water level. It is suspected that lake water level might be declining due to this newly emerged seepage. In view of these concerns, the present study has been carried out for the investigation of the source of seepage water and its likely connection with the lake water. It includes: (1) study of lake water level trend, (2) collection of water samples in and around seepage site, from the lake and 
springs, and on-site measurement of their physical properties (temperature and electrical conductivity), and (3) isotopic $\left(\delta^{2} \mathrm{H},{ }^{3} \mathrm{H}\right.$, and $\left.\delta^{18} \mathrm{O}\right)$ and chemical $\left(\mathrm{Ca}^{++}, \mathrm{Mg}^{++}, \mathrm{Na}^{+}, \mathrm{K}^{+}, \mathrm{SO}_{4}^{--}\right.$and $\left.\mathrm{Cl}^{-}\right)$ characterization of the water samples.

\section{Study area}

Nainital town $\left(\sim 14.32 \mathrm{~km}^{2}\right)$, surrounding the Lake Nainital is an important hill station of North India. The crescent-shaped lake $(1.5 \mathrm{~km}$ long and 0.36 $\mathrm{km}$ wide) basin, bounded between latitudes of $29^{\circ} 22^{\prime} 44^{\prime \prime}$ and $29^{\circ} 24^{\prime} \mathrm{N}$, and longitudes of $79^{\circ} 26^{\prime} 13^{\prime \prime}$ and $79^{\circ} 28^{\prime} 5^{\prime \prime} \mathrm{E}$ was discovered in $1841 \mathrm{AD}$ (Choudhary et al. 2009). It is close to the Main Boundary Thrust (MBT) that separates the Siwaliks from the Lesser Himalaya (Valdiya 1988; Anbalagan and
Singh 1996). Lake Nainital with a surface area of $0.46 \mathrm{~km}^{2}$ and mean depth of $16.5 \mathrm{~m}$ has a maximum capacity of 8.57 million $\mathrm{m}^{3}$ (Nachiappan et al. 2002). The area of the lake basin is $3.49 \mathrm{~km}^{2}$ excluding Sukhatal sub-basin. The Nainital Lake is bounded by the Sher-ka-Danda hill in the east, the landslide flat deposit in the north, the Ayarpatta hill in the west and Balia ravine in the south (Valdiya 1988). The seepage site is located downstream of Lake Nainital near Hotel Rais at an altitude of $1800 \mathrm{~m}$ (figure 1). The region is characterized by rugged topography and elevation has been found from $1400 \mathrm{~m}$ to more than $2400 \mathrm{~m}$. A major part of the area has hill slopes varying from $20^{\circ}$ to $25^{\circ}$ with a mean value of $19^{\circ}$. The maximum observed hill slope is $49^{\circ}$ whereas minimum $1^{\circ}$ at flats (Rawat 1987).
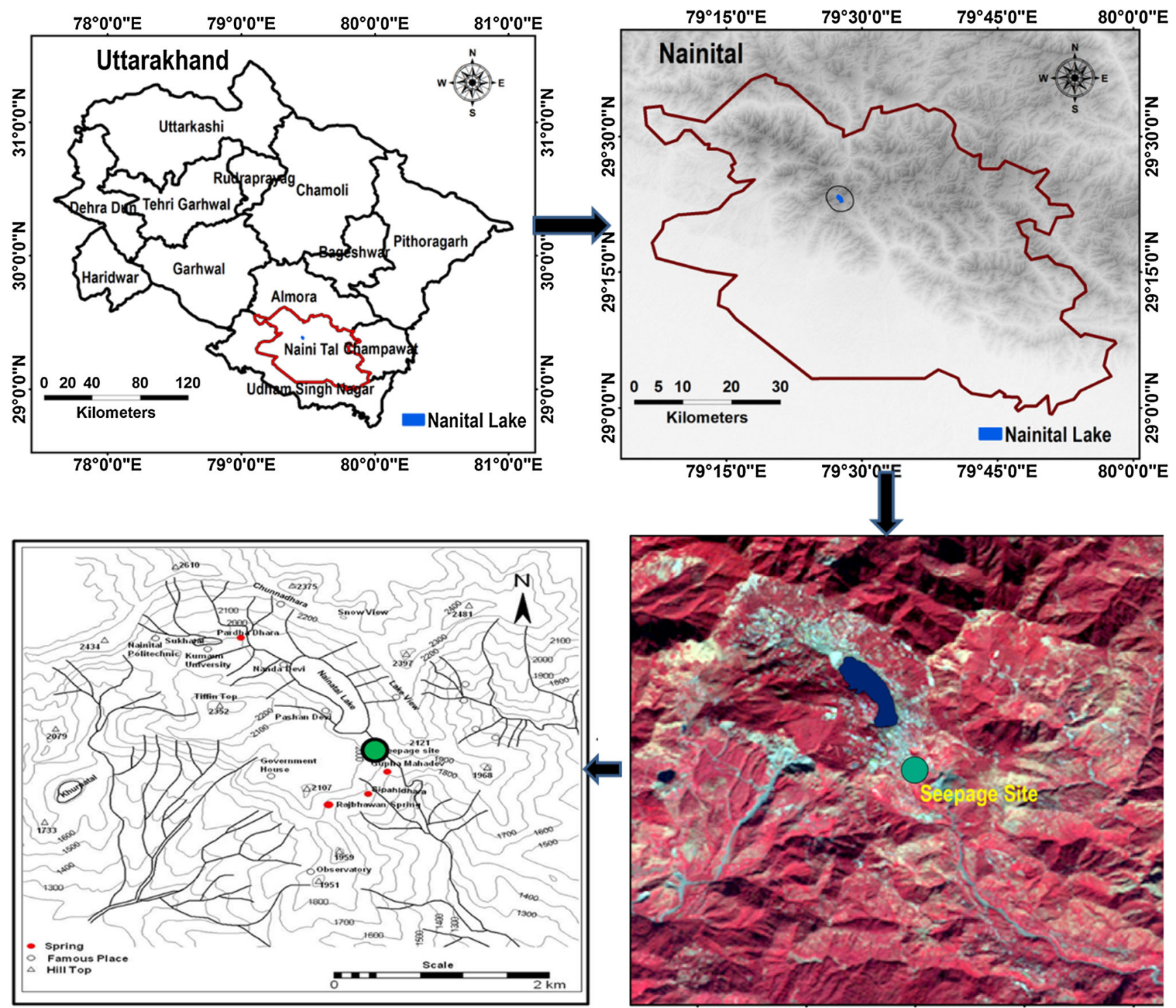

Figure 1. Map showing location of Lake Nainital along with seepage site and springs. 
Geologically, the catchment of Lake Nainital, is surrounded by the lithology of the Krol Formation (Precambrian). This mainly consists of carbonate rocks, such as limestone, dolomite, gypsum, calcareous slates, ferruginous shales, greywackes, etc. (Purushothaman et al. 2012). Argillaceous limestone and marlites rocks are exclusively found in the north-western part, whereas the south-western part comprises dolomite with limestone and black carbonaceous slates (Valdiya 1988). The rocks, in and around the seepage area, belong to Krol Group of rocks. The rocks are highly sheared and crushed as the contact between middle and upper Krol is faulted. Because of this, a number of springs are emerging near the seepage site (figure 1). Similarly, drainage pattern developed in the catchment bears the imprint of structural control as the area to the west of the lake is marked by very few streams, while the area to the east is characterized by several parallel to sub-parallel streams (Rawat 1988).

The study area experiences the climate of subtropical to sub-humid. The long-term (1901-2000) mean annual temperature $\left(T_{\text {Mean }}\right)$ is $24.50^{\circ} \mathrm{C}$. The mean monthly maximum temperature $\left(T_{\mathrm{Max}}\right)$ varies between $21.01^{\circ} \mathrm{C}$ (January) and $39.56^{\circ} \mathrm{C}$ (May) and the mean monthly minimum $\left(T_{\text {Min }}\right)$ from $7.18^{\circ} \mathrm{C}$ (January) to $26.36^{\circ} \mathrm{C}$ (June). The minimum $\left(7.76^{\circ} \mathrm{C}\right)$ and maximum $\left(15.97^{\circ} \mathrm{C}\right)$ diurnal variations in temperature are noted between August and April, respectively. The mean annual rainfall is $1897.13 \mathrm{~mm}$ and around $86 \%$ of total annual rainfall is received from south-west monsoon (Singh et al. 2016). Monsoon period in the Nainital lake catchment is observed from midJune to mid-September and the precipitation is moderate to heavy. During winter (December to mid-March), the precipitation is generally light to moderate with occasional snowfall. The detailed hydrological studies of Lake Nainital was carried out by Saravana Kumar et al. (2001). However, Singh et al. (2001) studied hydrological budget of the lake and estimated the contribution of surface runoff, subsurface inflow, drain inflow, and direct rainfall which were found to be $25 \%, 43 \%, 17 \%$, and $15 \%$, respectively.

Nainital town, which was first colonised in the 1850's, nurtured into a town of 7500 people by 1901 and to 40,000 by 2001 (Singh et al. 2001). The favourable climate and location of the Lake Nainital attract a large number of tourists ranging from 300,000 to 400,000 annually. In recent past, the lake has witnessed serious environmental threats due to the increased anthropogenic activities and global climate change. A significant decrease in mean annual rainfall including monsoonal rainfall, and increase (statistically insignificant) in annual mean temperature, maximum temperature and minimum temperature were reported for the lake catchment during the 20th century, i.e., 1901-2000 (Singh et al. 2016). This, in turn, has affected the hydrological regime of the lake (Bartarya and Valdiya 1989; Kumar et al. 1999; Singh et al. 2016). The increasing population pressure has not only raised the demand for fresh water supply, but also resulted in deforestation and intensive construction activities within the lake catchment, making the lake more vulnerable to anthropogenic activities.

\section{Materials and methods}

\subsection{Hydro-meteorological data and sample collection}

The daily water level of Lake Nainital and rainfall data starting from 1st October 2009 to 31st June 2012 were acquired from Public Works Department, Nainital. A field survey was conducted between 12th and 13th June 2012, and samples were collected in and around seepage site from 19 different sites including springs and the lake (table 1).

A total of three samples were taken from each site, one for chemical analysis (cation and anion) and two for isotopic analysis. The water samples were collected in high-density polyethene (HDPE) bottles of $500 \mathrm{~mL}$ (tritium), $125 \mathrm{~mL}$ (chemical) and $50 \mathrm{~mL}$ (stable isotope) sizes. The bottles were rinsed at the site with the sample water, filled without air bubble, tightly capped (to prevent evaporation and exchange with the atmospheric moisture), and brought to the laboratory for chemical and isotopic analysis. Lake water samples were collected at every $3 \mathrm{~m}$ successive depths from surface to bottom $(0-19 \mathrm{~m})$, in the middle of the lake, to monitor surface and depth-wise variation. This was collected using a depth sampler of $2 \mathrm{~L}$ capacity with a built-in thermometer of $0.02^{\circ} \mathrm{C}$ least count. The water samples were collected directly from the sites, filtered and preserved as per standard procedures (Appelo 1988). In order to avoid any precipitate of trace elements, the samples collected for cations were acidified using $\mathrm{HNO}_{3}$ to $\mathrm{pH} \approx 2$ in the field. While unfiltered samples were collected for analysis of anions. 


\subsection{Methodology}

\subsubsection{Physio-chemical methods}

The temperature and electrical conductivity (EC) of water were measured in-situ. Before the measurement, the EC and temperature meters were calibrated. The chemical parameters of water samples such as $\mathrm{Ca}^{++}, \mathrm{Mg}^{++}, \mathrm{Na}^{+}, \mathrm{K}^{+}, \mathrm{SO}_{4}^{--}$ and $\mathrm{Cl}^{-}$were analysed using a Dionex IC-5000, Ion Chromatograph (IC) at the Nuclear Hydrology Laboratory of National Institute of Hydrology Roorkee, India. The instrument was calibrated for analysis of major ions using M/s Dionex ${ }^{\circledR}$ elemental standards. The overall accuracy of the chemical analysis as determined by replicate measurements is found to be better than $\pm 5 \%$.

\subsubsection{Isotopic method}

The analysis of stable isotopes $\left(\delta^{2} \mathrm{H}\right.$ and $\left.\delta^{18} \mathrm{O}\right)$ requires measuring the fractionization (isotope partitioning) of $\delta^{2} \mathrm{H}$ and $\delta^{18} \mathrm{O}$ which are produced mainly by equilibrium isotopic exchange and kinetic processes (Ahmed et al. 2006). The oxygen and hydrogen isotopic measurements were carried out using a Dual Inlet Isotope Ratio Mass Spectrometer (Isoprime GV instruments, UK) with automatic sample preparation units at the Nuclear Hydrology Laboratory of National Institute of Hydrology, Roorkee, India. For oxygen and hydrogen isotopic measurement, $400 \mu \mathrm{L}$ water samples were taken and equilibrated with $\mathrm{CO}_{2}$ and $\mathrm{H}_{2}$ gas, separately at $40^{\circ} \mathrm{C}$ for 2 and $4 \mathrm{hrs}$, respectively. Hokobeads were used as the catalyst in the case of hydrogen isotope measurement. Secondary standards developed with reference to the primary V-SMOW, SLAP, Greenland Ice Sheet Precipitation (GISP) were also measured along with each batch of samples and the final $\delta$-values were calculated using a triple point calibration equation following the standard procedure (Epstein and Mayeda 1953; Brenninkmeijer and Morrison 1987). The overall precision, based on 10 repeated measurements of each sample, was within the error limits of $\pm 0.1 \%$ for $\delta^{18} \mathrm{O}$ and $\pm 1 \%$ for $\delta^{2} \mathrm{H}$.

The Ultra-Low-Level Liquid Scintillation Counter (ULLSC) was used in the measurement of ${ }^{3} \mathrm{H}$ which is an excellent dating tool for studying timescales of physical processes in hydrologic systems in the range of years to decades (Stewart and Morgenstern 2016). First of all, a $500 \mathrm{ml}$ of pre-distilled water sample was enriched using an electrolytic cell having mild steel cathode and stainless steel anode with sodium peroxide as an electrolyte. By passing electric current through a conducting water solution, the bonds of the water molecules broke with the evolution of hydrogen and oxygen gases. The temperature of the sample was maintained at $0^{\circ} \mathrm{C}$ and $5^{\circ} \mathrm{C}$ in order to achieve maximum fractionation or enrichment of HTO (tritium water). The water sample of $500 \mathrm{~mL}$ was reduced to 25 $\mathrm{mL}$. These enriched samples were again distilled and mixed with an organic scintillator (Optiphase Hisafe-3) in a $20 \mathrm{ml}$ capacity scintillation vial. The vials were measured for $400 \mathrm{~min}$ using ULLSC. In hydrological applications, tritium concentration in water samples is usually expressed as tritium units (TU) and 1 TU activity represents one atom of tritium per $10^{18}$ hydrogen atoms (i.e., $\mathrm{T} / \mathrm{H}=10^{-18}$ and $1 \mathrm{TU}=0.118 \mathrm{~Bq} \mathrm{~kg}^{-1}$ activity of water). The minimum detectable level of the instrument without enrichment is $9.8 \mathrm{TU}$ and it is upto $0.6 \mathrm{TU}$ with enrichment within the level of $2 \sigma$ error $(95 \%$ confidence level).

\section{Results and discussion}

\subsection{Lake water level trend analysis}

The effects of rainfall variability and water extraction through pumping on the lake water level were investigated. A continuous decline in the lake water level was observed from the end of October to 2nd/3rd week of June and the declining pattern was almost similar for all the three years, i.e., 2009-2012 (figure 2). This was also evident from the study of regression analysis. The declining rate of the lake water was found between 1.3 and 1.4 $\mathrm{m} /$ month. However, a rise in the lake water level was recorded with an onset of the monsoon that continued up to September/October depending on the pattern of monsoon rainfall. It was noted that the lake region had received relatively more rainfall in winter and pre-monsoon seasons during the years 2010 and 2011 than those of the year 2012. During 2012 , only one event of rainfall was recorded in the pre-monsoon season (April).

The pumping data for all the 12 tubewells, installed at the bank of the lake, were obtained from the Department of Public Health Engineering (PHE), Nainital. The analysis of data shows that during the year 2008-2009 approximately 9 mld (million litres per day) was pumped through all the tubewells which reached more than 18 mld 
Table 1. Sampling sites along with physio-chemical and isotopic properties of springs, seepage and lake water

\begin{tabular}{|c|c|c|c|c|c|c|c|}
\hline ID & Source types & Location & Latitude & Longitude & $\begin{array}{l}\text { Altitude } \\
(\mathrm{m})\end{array}$ & $\begin{array}{l}\text { Temp. } \\
\left({ }^{\circ} \mathrm{C}\right)\end{array}$ & $\begin{array}{l}\mathrm{EC} \\
(\mu \mathrm{S} / \mathrm{cm})\end{array}$ \\
\hline NTL-1 & Spring & $\begin{array}{l}\text { Natural flow to } \\
\text { Nala, not tapped }\end{array}$ & $29^{\circ} 22^{\prime} 22^{\prime \prime}$ & $79^{\circ} 27^{\prime} 58.5^{\prime \prime}$ & 1802 & 17.4 & 370 \\
\hline NTL-2 & Spring & $\begin{array}{l}\text { Spring tapped for } \\
\text { drinking water }\end{array}$ & $29^{\circ} 22^{\prime} 24^{\prime \prime}$ & $79^{\circ} 27^{\prime} 59.4^{\prime \prime}$ & 1802 & 17.3 & 350 \\
\hline NTL-3a & Seepage & Seepage water & $29^{\circ} 22^{\prime} 24.7^{\prime \prime}$ & $79^{\circ} 27^{\prime} 59.5^{\prime \prime}$ & 1807 & 17.5 & 390 \\
\hline NTL-3b & Seepage & Seepage water & $29^{\circ} 22^{\prime} 24.7^{\prime \prime}$ & $79^{\circ} 27^{\prime} 59.5^{\prime \prime}$ & 1801 & 18.5 & 320 \\
\hline NTL-4 & Spring & $\begin{array}{l}\text { Gupha Mahadev } \\
\text { seepage near road }\end{array}$ & $29^{\circ} 22^{\prime} 18.6^{\prime \prime}$ & $79^{\circ} 27^{\prime} 55.2^{\prime \prime}$ & 1764 & 17.4 & 410 \\
\hline NTL-5a & Spring & $\begin{array}{l}\text { Gupha Mahadev } \\
\text { temple }\end{array}$ & $29^{\circ} 22^{\prime} 18.4^{\prime \prime}$ & $79^{\circ} 27^{\prime} 55.2^{\prime \prime}$ & 1765 & 17.4 & 410 \\
\hline NTL-5b & Spring & $\begin{array}{l}\text { Gupha Mahadev } \\
\text { temple drops }\end{array}$ & $29^{\circ} 22^{\prime} 18.2^{\prime \prime}$ & $79^{\circ} 27^{\prime} 55.2^{\prime \prime}$ & 1766 & 17.4 & 400 \\
\hline NTL-6a & Spring & Sipahi Dhara & $29^{\circ} 22^{\prime} 21.2^{\prime \prime}$ & $79^{\circ} 27^{\prime} 50.3^{\prime \prime}$ & 1856 & 16.2 & 420 \\
\hline NTL-6b & Spring & Sipahi Dhara & $29^{\circ} 22^{\prime} 21.4^{\prime \prime}$ & $79^{\circ} 27^{\prime} 50.4^{\prime \prime}$ & 1856 & 16.3 & 420 \\
\hline NTL-6c & Spring & Sipahi Dhara & $29^{\circ} 22^{\prime} 21.3^{\prime \prime}$ & $79^{\circ} 27^{\prime} 50.4^{\prime \prime}$ & 1856 & 16.0 & 420 \\
\hline NTL-7 & Spring & Rajbhawan Spring & $29^{\circ} 22^{\prime} 15.4^{\prime \prime}$ & $79^{\circ} 27^{\prime} 36.2^{\prime \prime}$ & 1885 & 20.9 & 370 \\
\hline NTL-8 & Nainital Lake & Lake $0 \mathrm{~m}$ (depth) & $29^{\circ} 22^{\prime} 10.5^{\prime \prime}$ & $79^{\circ} 27^{\prime} 36.8^{\prime \prime}$ & 1929 & 23.1 & 430 \\
\hline NTL-9 & Nainital Lake & Lake 3 m (depth) & $29^{\circ} 22^{\prime} 10.5^{\prime \prime}$ & $79^{\circ} 27^{\prime} 36.8^{\prime \prime}$ & - & 22 & 430 \\
\hline NTL-10 & Nainital Lake & Lake 6 m (depth) & $29^{\circ} 22^{\prime} 10.5^{\prime \prime}$ & $79^{\circ} 27^{\prime} 36.8^{\prime \prime}$ & - & 21 & 430 \\
\hline NTL-11 & Nainital Lake & Lake $9 \mathrm{~m}$ (depth) & $29^{\circ} 22^{\prime} 10.5^{\prime \prime}$ & $79^{\circ} 27^{\prime} 36.8^{\prime \prime}$ & - & 20.8 & 430 \\
\hline NTL-12 & Nainital Lake & Lake $12 \mathrm{~m}$ (depth) & $29^{\circ} 22^{\prime} 10.5^{\prime \prime}$ & $79^{\circ} 27^{\prime} 36.8^{\prime \prime}$ & - & 20.8 & 440 \\
\hline NTL-13 & Nainital Lake & Lake 15 m (depth) & $29^{\circ} 22^{\prime} 10.5^{\prime \prime}$ & $79^{\circ} 27^{\prime} 36.8^{\prime \prime}$ & - & 20.4 & 450 \\
\hline NTL-14 & Nainital Lake & Lake 18 m (depth) & $29^{\circ} 22^{\prime} 10.5^{\prime \prime}$ & $79^{\circ} 27^{\prime} 36.8^{\prime \prime}$ & - & 20.3 & 460 \\
\hline NTL-15 & Nainital Lake & Lake 19 m (depth) & $29^{\circ} 22^{\prime} 10.5^{\prime \prime}$ & $79^{\circ} 27^{\prime} 36.8^{\prime \prime}$ & - & 20.2 & 460 \\
\hline
\end{tabular}

in the month of June in 2010. For 2011 and 2012, it was lowest in December and the highest was about 18 mld in June for both the years. It indicates that there is no sudden increase in pumping. Therefore, the impact of pumping on the declining of the lake level in the year 2012 is same, as it was in the year 2011.

\subsection{Physio-chemical characteristics of lake and seepage water}

Significant variations in the temperature, EC and water quality parameters were observed in the lake water, the springs and the seepage waters (table 1). The temperature of the lake water measured in-situ was found to be varying between $23.1^{\circ} \mathrm{C}(0 \mathrm{~m}$ depth $)$ and $20.2^{\circ} \mathrm{C}(19 \mathrm{~m}$ depth $)$. It was relatively higher than that of the springs $\left(16^{\circ}\right.$ and $\left.20.9^{\circ} \mathrm{C}\right)$ and seepage waters $\left(17.5^{\circ}\right.$ and $\left.18.5^{\circ} \mathrm{C}\right)$, respectively. The reason for the higher temperature of the lake water up to a depth of $9 \mathrm{~m}$ is the thermal stratification of the lake (Saravana Kumar et al. 2008). Lake Nainital remains stratified for 9 months from March to November (Nachiappan et al. 2002). Below this depth, the temperature of the lake water was measured between $20.8^{\circ} \mathrm{C}$ and $\sim 20^{\circ} \mathrm{C}$. Besides, variation in the value of $\mathrm{EC}$ of the waters of the lake, springs and seepage was also perceived. The lake water was characterized with the slightly higher values of EC. It was found between $430(0 \mathrm{~m}$ depth $)$ and $460 \mu \mathrm{S} / \mathrm{cm}(19 \mathrm{~m}$ depth). However, EC of the springs and seepage water fell in the range of $350-420 \mu \mathrm{S} / \mathrm{cm}$ and 320 $390 \mu \mathrm{S} / \mathrm{cm}$, respectively. The higher EC in the lake water might occur due to the artificial circulation of the lake water prompted for the mixing of oxygen in the lake through the artificial device, which has been installed recently in the lake to avoid the fish mortality and improve the water quality of the lake. The difference in the values of EC was measured for the lake and seepage water. In contrast, the seepage water shows affinity with the physical characteristics of the groundwater.

The chemistry of the lake and spring waters were mainly dominated by $\mathrm{Ca}^{++}$and $\mathrm{Mg}^{++}$due to the presence of limestone and dolomite rocks in the lake catchment (Saini et al. 2008; Purushothaman et al. 2012). Therefore, other cations $\left(\mathrm{Na}^{+}\right.$and $\left.\mathrm{K}^{+}\right)$ and anions $\left(\mathrm{Cl}^{-}\right.$and $\left.\mathrm{SO}_{4}{ }^{--}\right)$were also analyzed to understand similarity between seepage water 
Table 1. (Continued.)

\begin{tabular}{|c|c|c|c|c|c|c|c|c|}
\hline ID & $\begin{array}{l}\mathrm{Cl}^{-} \\
(\mathrm{mg} / \mathrm{l})\end{array}$ & $\begin{array}{l}\mathrm{SO}_{4}^{--} \\
(\mathrm{mg} / \mathrm{l})\end{array}$ & $\begin{array}{l}\mathrm{Na}^{+} \\
(\mathrm{mg} / \mathrm{l})\end{array}$ & $\begin{array}{l}\mathrm{K}^{+} \\
(\mathrm{mg} / \mathrm{l})\end{array}$ & $\begin{array}{l}\mathrm{Mg}^{++}+ \\
\mathrm{Ca}^{++} \\
(\mathrm{mg} / \mathrm{l})\end{array}$ & $\begin{array}{l}\delta^{2} \mathrm{H} \\
(\%)\end{array}$ & $\begin{array}{l}\delta^{18} \mathrm{O} \\
(\%)\end{array}$ & $\begin{array}{l}{ }^{3} \mathrm{H} \\
(\mathrm{TU})\end{array}$ \\
\hline NTL-1 & 14.7 & 85.48 & 20.17 & 27.07 & 277.99 & -64.6 & -9.3 & \\
\hline NTL-2 & 20.4 & 80.63 & 25.55 & 43.27 & 272.47 & -64.7 & -9.4 & 4.3 \\
\hline NTL-3 & 16.6 & 80.8 & 22.08 & 31.48 & 271.45 & -65.3 & -9.4 & 3.5 \\
\hline NTL-3a & 21.4 & 82.71 & 26.64 & 37.87 & 250.2 & -65.0 & -9.3 & 3.9 \\
\hline NTL-4 & 13.3 & 81.03 & 17.41 & 24.91 & 276.95 & -62.9 & -9.4 & \\
\hline NTL-5a & 13.5 & 81.02 & 17.39 & 24.91 & 274.91 & -62.9 & -9.4 & \\
\hline NTL-5b & 13.2 & 81.03 & 17.40 & 24.93 & 276.96 & -63.3 & -9.3 & \\
\hline NTL-6a & 11.8 & 78.78 & 14.47 & 19.12 & 248.19 & -64.5 & -9.3 & \\
\hline NTL-6b & 12.4 & 82.37 & 15.7 & 20.55 & 269.11 & -64.4 & -9.4 & 4.1 \\
\hline NTL-6c & 12.4 & 81 & 15.4 & 21.13 & 260.15 & -64.2 & -9.3 & \\
\hline NTL-7 & 14.0 & 76.19 & 14.09 & 25.74 & 203.03 & -68.6 & -9.9 & \\
\hline NTL-8 & 9.5 & 74.91 & 14.78 & 20.74 & 238.08 & -62.2 & -8.7 & 4.3 \\
\hline NTL-9 & 10 & 77.07 & 16.04 & 23.36 & 257.43 & -62.8 & -8.7 & \\
\hline NTL-10 & 9.8 & 75.11 & 16.17 & 22.37 & 253.36 & -62.6 & -8.8 & \\
\hline NTL-11 & 10.02 & 74.33 & 15.1 & 21.1 & 232.62 & -62.2 & -8.7 & \\
\hline NTL-12 & 10.1 & 77.92 & 16.49 & 23.51 & 263.82 & -62.5 & -8.9 & \\
\hline NTL-13 & 10.1 & 76.93 & 16.17 & 22.38 & 253.36 & -62.9 & -8.8 & \\
\hline NTL-14 & 9.7 & 76.51 & 15.81 & 22.59 & 249.96 & -62.2 & -8.8 & \\
\hline NTL-15 & 10.4 & 80.15 & 17.23 & 23.9 & 271.87 & -64.9 & -8.7 & 2.9 \\
\hline
\end{tabular}

and lake water. The summary of chemical analyses of the collected samples is given in table 1 . The higher concentration of $\mathrm{Ca}^{++}$and $\mathrm{Mg}^{++}$in the seepage, as well as the lake water, are mainly due to dissolution of dolomitic rocks. Similarly, the dissolution of pyrites is thought to be the ground for the high concentration of sulphate in the waters (lake and ground/seepage) of the catchment (Middlemiss 1890; Coulson 1939). Ashraf (1978) and Valdiya (1988) were amongst the earlier investigators who pointed towards the pyrification of the slates and dolomites. The oxidation and hydrolysis of pyrite produce sulphuric acid and soluble sulphates as given below (Karanth 1987):

$$
\begin{aligned}
& 2 \mathrm{FeS}_{2}+7 \mathrm{H}_{2} \mathrm{O}+15 \mathrm{O} \rightarrow 2 \mathrm{Fe}(\mathrm{OH})_{3}+4 \mathrm{H}_{2} \mathrm{SO}_{4} \\
& \mathrm{FeS}_{2}+\mathrm{H}_{2} \mathrm{O}+7 \mathrm{O} \rightarrow 2 \mathrm{FeSO}_{4}+\mathrm{H}_{2} \mathrm{SO}_{4} \\
& 2 \mathrm{FeSO}_{4}+\mathrm{H}_{2} \mathrm{SO}_{4}+\mathrm{O} \rightarrow \mathrm{Fe}_{2}\left(\mathrm{SO}_{4}\right)_{3}+\mathrm{H}_{2} \mathrm{O}
\end{aligned}
$$

Sulphuric acid thus formed reacts with calcite in the weathered zones and calcareous rocks to produce soluble calcium sulphate:

$$
\mathrm{H}_{2} \mathrm{SO}_{4}+\mathrm{CaCO}_{3} \rightarrow \mathrm{H}_{2} \mathrm{CO}_{3}+\mathrm{CaSO}_{4} .
$$

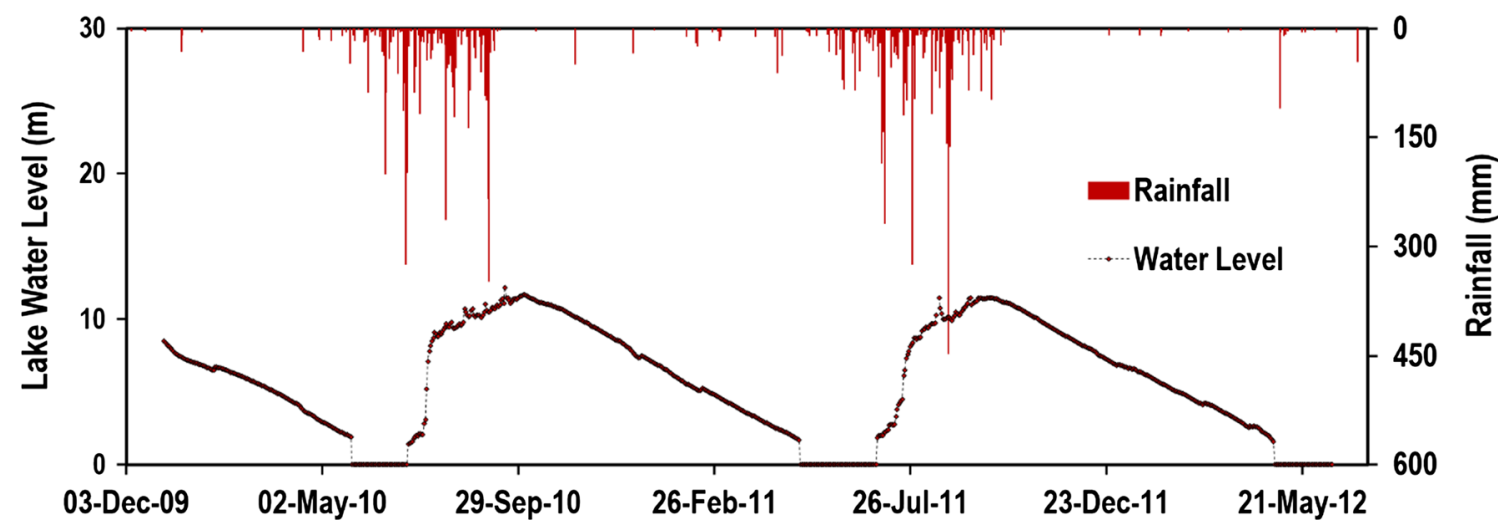

Figure 2. Temporal variation of the water level with rainfall (zero water level indicates in datum, chosen for measuring the lake water level data). 


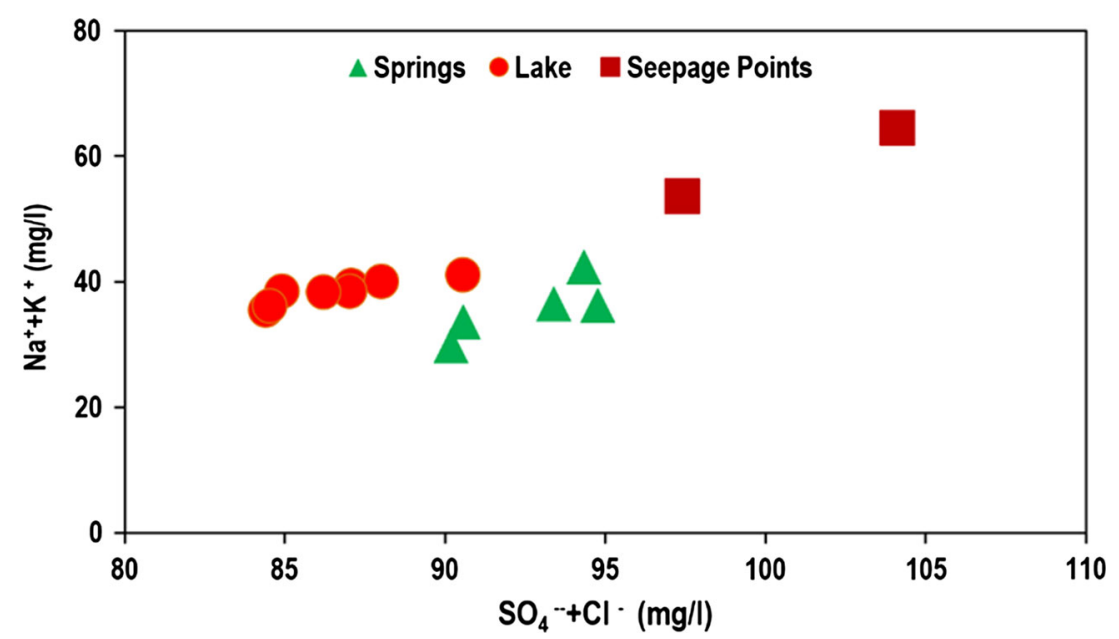

Figure 3. Variation of $\mathrm{Na}^{+}+\mathrm{K}^{+}$with $\mathrm{SO}_{4}^{--}+\mathrm{Cl}^{-}$in lake, springs and seepage water.

The concentration of $\mathrm{Na}^{+}$in the lake water varied from 14.78 to $17.23 \mathrm{mg} / \mathrm{L}$. However, it was found between 14.09 and $26.64 \mathrm{mg} / \mathrm{L}$ for the springs and between 22.08 and $26.64 \mathrm{mg} / \mathrm{L}$ for the seepage water. The seepage water was also characterized by a higher concentration of $\mathrm{K}^{+}$ion, i.e., $31.48-37.87 \mathrm{mg} / \mathrm{L}$ than that of the lake water (20.74-23.90 mg/L). The low concentration of $\mathrm{Na}^{+}$ and $\mathrm{K}^{+}$in the lake water was also reported by Purushothaman et al. (2012).

Sodium in natural waters may be derived from silicate minerals, atmospheric precipitation and halite deposits. In silicate rocks, it is mainly present as albite component of plagioclase (Saini et al. 2008). Opposite to this, Nainital lake catchment is mainly dominated by dolomitic limestone and devoid of silicates. Therefore, the high concentration of $\mathrm{K}^{+}$and $\mathrm{Na}^{+}$in seepage water may be attributed to anthropogenic activities apart from the dissolution of rocks (Saini et al. 2008).

Chloride $\left(\mathrm{Cl}^{-}\right)$, the most conservative ion among all the major ions, dissolved in water, is a good tracer of water (Drever 1988). The plot of $\mathrm{Na}^{+}+\mathrm{K}^{+}$ vs. $\mathrm{SO}_{4}{ }^{--}+\mathrm{Cl}^{-}$was also used to understand the similarity in the chemistry of all samples collected from the study area (figure 3 ). The results indicate that the concentrations of $\mathrm{Na}^{+}+\mathrm{K}^{+}$and $\mathrm{SO}_{4}{ }^{--}+\mathrm{Cl}^{-}$are comparatively higher in seepage water compared to the lake water. The comparatively low concentration of sulphate and chloride in lake water is attributed to the fact that it is a mixture of surface water $(25 \%)$, subsurface water (43\%), drain discharge (17\%) and direct precipitation $(15 \%)$ on the lake surface (Singh et al. 2001). Results derived from the chemical analysis suggested that cation and anion compositions of the seepage water are significantly different from that of the lake water.

\subsection{Isotopic composition of lake and seepage water}

Water samples were analysed for their isotopic signatures to identify the source of seepage and their likely connection with the lake water. The water bodies generally inherit the isotopic mark of its recharge water. But, variations in their stable isotopic compositions $\left(\delta^{18} \mathrm{O}\right.$ and $\left.\delta^{2} \mathrm{H}\right)$ may take place from that of their original recharge water sources due to the isotopic fractionation or through the mixing of water from other sources. While, variation in ${ }^{3} \mathrm{H}$ is due to the residence time of water. Therefore, isotopic signatures are used as fingerprint to identify the sources and recharge zones (Craig 1961; Yao et al. 2000; Song et al. 2006). The differences observed, in the values of $\delta^{2} \mathrm{H}$ and $\delta^{18} \mathrm{O}$, and ${ }^{3} \mathrm{H}$ in the lake water and seepage water were used for determining mixing processes between the two water systems. The results of the isotopic analysis $\left(\delta^{2} \mathrm{H}, \delta^{18} \mathrm{O}\right.$ and $\left.{ }^{3} \mathrm{H}\right)$ are displayed in table 1 . There are significant differences in values of $\delta^{18} \mathrm{O}$ measured for the lake, springs and seepage water. $\delta^{18} \mathrm{O}$ in the lake water varied from $-8.7 \%$ to $-8.9 \%$, while it was found in the range of $-9.3 \%$ to $-9.9 \%$ for the springs and from $-9.3 \%$ to $-9.4 \%$ for the seepage water. The isotopic signature of the seepage water showed a close resemblance with groundwater (springs) in terms of isotope values. Similarly, differences in values of ${ }^{3} \mathrm{H}$ were also observed in the lake water and seepage water. The concentration of tritium $\left({ }^{3} \mathrm{H}\right)$ in the lake water was measured 4.32 and $2.94 \mathrm{TU}$ at the top of surface $(0 \mathrm{~m})$ and at the depth of $19 \mathrm{~m}$, 


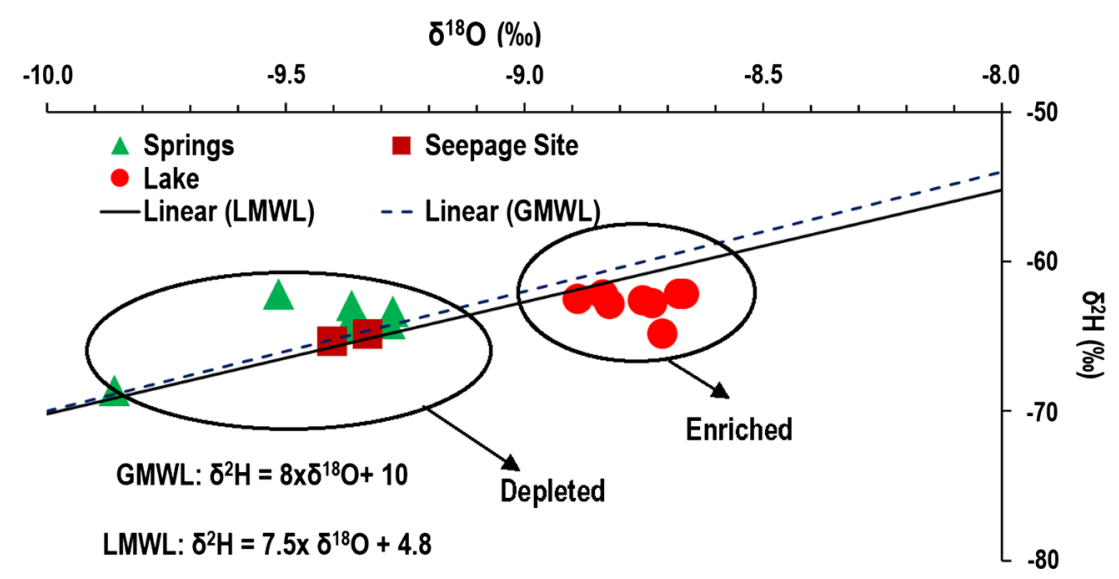

Figure 4. Isotopic composition of lake, spring and seepage water.
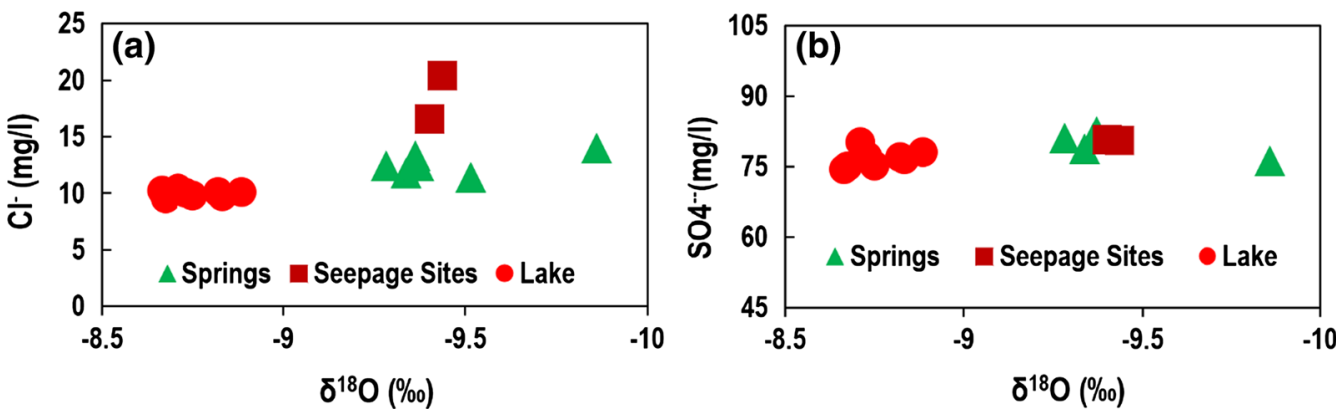

Figure 5. Variation of chloride $\left(\mathrm{Cl}^{-}\right)$and sulphate $\left(\mathrm{SO}_{4}{ }^{--}\right)$with $\delta^{18} \mathrm{O}$ in lake, springs and seepage water.

respectively. This variation within the lake water was attributed to the stratification of lake during summer months. However, it was found between 3.52 and $3.85 \mathrm{TU}$ for the seepage water.

A local meteoric water line (LMWL), developed by Saravana Kumar et al. (2008), for Lake Nainital catchment is shown in figure 4 along with a Global Meteoric Water Line (GMWL). GMWL is constructed with $\delta^{2} \mathrm{H}$ and $\delta^{18} \mathrm{O}$ of precipitation occurring all over the world. The equation $\left(\delta^{2} \mathrm{H}=8 * \delta^{18} \mathrm{O}+10\right)$ for this line was given by (Craig 1961). However, the best-fit regression line of the LMWL is:

$$
\delta^{2} \mathrm{H}=7.5 \times \delta^{18} \mathrm{O}+4.8(\% \mathrm{O} \text {-SMOW })
$$

LMWL shows its resemblance in terms of slope and intercept with GMWL; however, it has the slope and intercept, slightly lower than the GMWL. This difference may be because of mixing of local air moisture masses in the precipitation coupled with change in weather and topographical conditions (Kumar et al. 2010).

The stable isotopic $\left(\delta^{2} \mathrm{H}\right.$ and $\left.\delta^{18} \mathrm{O}\right)$ data of the lake, springs and seepage waters are plotted on an $\mathrm{X}-\mathrm{Y}$ graph as shown in figure 4 with respect to the
LMWL. The springs and seepage samples almost fall on the LMWL. It reveals that the source of the springs and seepage water is the local precipitation. In contrast, the samples of Lake Nainital slightly fall off the LMWL. But, it shows close proximity with the LMWL in terms of isotopic signatures $\left(\delta^{2} \mathrm{H}\right.$ and $\left.\delta^{18} \mathrm{O}\right)$, and suggests that the local precipitation is also the source of its water. The deviation from the LMWL is due to evaporative fractionation of the lake water. The lake, being an open water body, is exposed to atmosphere and, therefore, is characterised with enriched isotopic signatures than that of the seepage and spring waters. Due to this enrichment, samples of lake water were congregated and fall on the upper side (enriched) of the LMWL, while of the springs and seepage on the lower side (depleted) of the LMWL.

The $\delta^{18} \mathrm{O}$ data along with other chemical data were also analysed to conclude the source of the seepage water (figure 5). The plot of $\delta^{18} \mathrm{O} v s$. $\mathrm{Cl}^{-}$showed that the lake water had comparatively lower chloride and enriched $\delta^{18} \mathrm{O}$ values than that of the seepage water (figure 5a). In contrast, seepage water characteristics are similar to the springs. But, the study of $\delta^{18} \mathrm{O}$ vs. $\mathrm{SO}_{4}{ }^{--}$ plot indicated that $\mathrm{SO}_{4}^{--}$values were with slight 


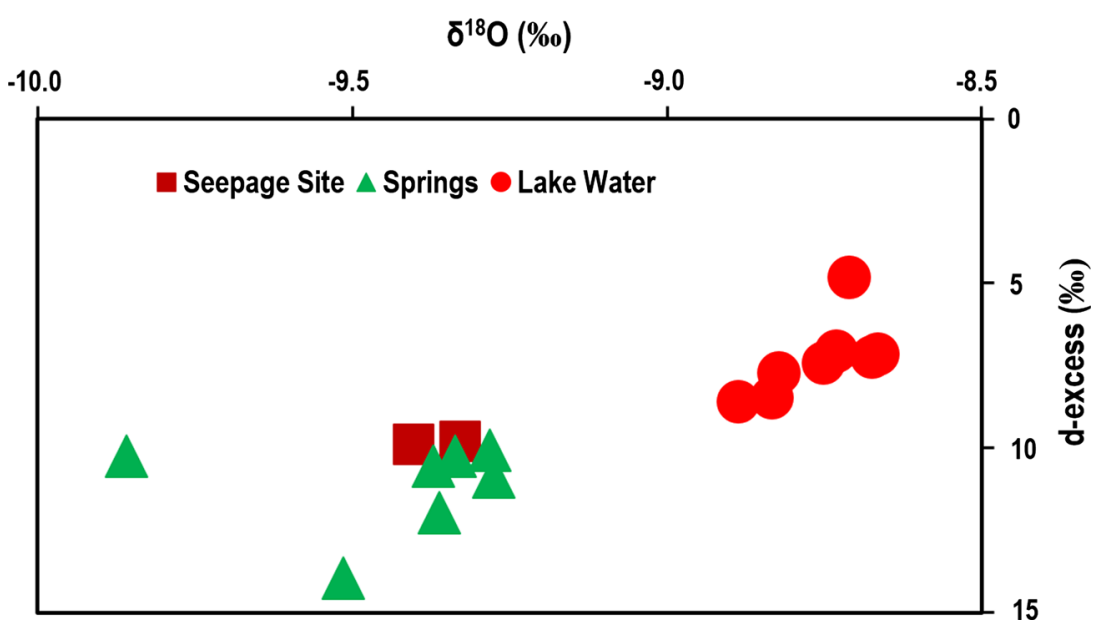

Figure 6. d-excess variation in lake, seepage and spring water.

difference in both the water due to similar geology in the recharge zones of lake and springs (figure $5 \mathrm{~b}$ ). However, the isotopic signature is depleted in seepage water and values are closer to the local ground-water sources.

\subsection{Computation of $d$-excess}

The deuterium excess or d-excess, as defined in equation (1) by Dansgaard (1964) is a measure of the relative proportions of $\delta^{18} \mathrm{O}$ and $\delta^{2} \mathrm{H}$ contained in water. This measures deviation in deuterium $\left({ }^{2} \mathrm{H}\right)$ relative to GMWL. d-excess reflects the prevailing conditions during evolution and interaction or mixing of air masses en route to the precipitation site (Froehlich et al. 2002).

$$
\mathrm{d}-\operatorname{excess}(\%)=\delta^{2} \mathrm{H}-8 \times \delta^{18} \mathrm{O}
$$

d-excess, as defined above, represents the excess $\delta^{2} \mathrm{H}$ than 8 times of $\delta^{18} \mathrm{O}$ for any water body or vapour. The magnitude of equilibrium fractionation (condensation) for $\delta^{2} \mathrm{H}$ is about 8 times to that for $\delta^{18} \mathrm{O}$. Thus, due to evaporation (non-equilibrium fractionation) from a water body, the d-excess of the evaporating water decreases, while it increases in water vapour. The d-excess in the Lake Nainital was found to be varying from $4 \%$ to $8 \%$ which was less than that of the seepage/springs, i.e., $9.8 \%$ to $10.70 \%$ (figure 6 ). The low d-excess of the lake is the result of strong evaporation or non-equilibrium fractionation of the lake water. However, d-excess of seepage water is more or less similar to springs which are recharged from the local precipitation occurring in the lake catchment (Saravana Kumar et al. 2008). The difference of $\delta^{2} \mathrm{H}$ and $\delta^{18} \mathrm{O}$ values, tritium $\left({ }^{3} \mathrm{H}\right)$ and $\mathrm{d}$-excess between seepage and lake water clearly indicates that the lake is not the source of newly emerged seepage water. Further, the difference in physico-chemical parameters of lake and seepage water corroborate the finding of isotopes.

\section{Conclusion}

The analysis of chemical and isotopic data shows that signatures of seepage water are not similar to that of the lake water. For example, $\delta^{18} \mathrm{O}$ in the lake water varies from $-8.7 \%$ to $-8.9 \%$, while it is found in the range of $-9.3 \%$ to $-9.4 \%$ for the seepage water. The d-excess of Lake Nainital is varying between $4 \%$ and $8 \%$ which is less than that of the seepage water $(9.8 \%)$. It implies that the lake is not contributing to the newly emerged seepage point through seepage/leakage. In addition, the higher concentrations of $\mathrm{Na}^{+}, \mathrm{K}^{+}$and $\mathrm{Cl}^{-}$in seepage water, in comparison to the lake water, also decline the possibility of hydraulic connectivity of the lake with the seepage. However, the fall observed in the lake water level during June 2012 may be linked to the lower rainfall of pre-monsoon months of the year 2012 and winter months of the year 2011-2012 in comparison to the previous years of 2009-2010 and 2010 2011, respectively. The outcomes of the present study show effectiveness of environmental isotopes $\left(\delta^{2} \mathrm{H}, \delta^{18} \mathrm{O}\right.$ and $\left.{ }^{3} \mathrm{H}\right)$ as 'tracers' in the identification of a the source of seepage and springs water in conjunction with other hydrochemical parameters. Further, it suggests that similar kinds of studies can also be extended to the other springs of the Lesser Himalayan region where discharge is declining, for identification of recharge source and 
zones of spring. The finding would be used for the water resource management of the springs.

\section{Acknowledgements}

The authors are grateful to Uttarakhand State Council for Science \& Technology (UCOST) for funding the project entitled 'Identification of Source of Seepage/Leakage around Lake Nainital, District Nainital, Uttarakhand'. The authors express their sincere gratitude to $\mathrm{Dr}$ R Dobhal, D.G., UCOST, Dehradun, Mr. Dinesh Chand Tamta (Executive Engineer), Mr. Hemchand Joshi (Assistant Engineer) and Mr. Pankaj Dhoundhiyal (Junior Engineer) of Irrigation Division, Nainital for their generous support in conducting the field survey. We are also thankful to Director, National Institute of Hydrology, Roorkee for providing all administrative and financial support for the successful completion of the study. We also extend our gratitude to the anonymous reviewers for their precious comments and suggestions which helped in improving the manuscript.

\section{References}

Adomako D, Gibrilla A, Maloszewski P, Ganyaglo S Y and Rai S P 2015 Tracing stable isotopes $\left(\delta^{2} \mathrm{H}\right.$ and $\left.\delta^{18} \mathrm{O}\right)$ from meteoric water to groundwater in the Densu River basin of Ghana; Environ. Monit. Assess. https://doi.org/10.1007/ s10661-015-4498-2.

Ahmed N, Wallin B G and Majumder R K 2006 Use of hydrochemistry and stable isotope techniques in investigating seepage/leakage in Gumti flood dyke, Comilla; J. Civil Eng. 34(2) 81-90.

Anbalagan R and Singh B 1996 Landslide hazard and risk assessment mapping of mountainous terrains - a case study from Kumaun Himalaya, India; Eng. Geol. 43(4) 237-246.

Appelo C A 1988 Hydrochemistry for Hydrogeologists: Application of Chemical Theory; Institute for Earth Sciences, VU Amsterdam.

Ashraf Z 1978 A geological report on the drilling explorations carried out for the study of Nainital hill slope stability, Nainital District, Uttar Pradesh; Unpublished Report, Geological Survey of India, EGD (E), Lucknow.

Bartarya S K and Valdiya K S 1989 Landslides and erosion in the catchment of the Gaula River, Kumaun Lesser Himalaya, India; Mt. Res. Dev. 9(4) 405-419, https:// doi.org/10.2307/3673588.

Bouchez C, Goncalves J, Deschamps P, Vallet-Coulomb C, Hamelin B, Doumnang J C and Sylvestre F 2016 Hydrological, chemical, and isotopic budgets of Lake Chad: A quantitative assessment of evaporation, transpiration and infiltration fluxes; Hydrol. Earth Syst. Sci. 20(4) 15991619, https://doi.org/10.5194/hess-20-1599-2016.
Brenninkmeijer C A and Morrison P D 1987 An automated system for isotopic equilibration of $\mathrm{CO}_{2}$ and $\mathrm{H}_{2} \mathrm{O}$ for ${ }^{18} \mathrm{O}$ analysis of water; Chem. Geol. (Isot. Geosci. Sect.) 6(1) 21-26.

Chen J and Dong H 2001 Study of fissured-rock seepage flow with isotope tracer method in single borehole; Sci. China Ser. E-Tech. Sci. 44(1) 108-113, https://doi.org/ 10.1007/BF02916799.

Choudhary P, Routh J, Chakrapani G J and Kumar B 2009 Biogeochemical records of paleoenvironmental changes in Nainital Lake, Kumaun Himalayas, India; J. Paleolimnol. 42(4) 571-586, https://doi.org/10.1007/ s10933-009-9306-y.

Clark I D and Fritz P 1997 Environmental isotopes in hydrogeology; CRC press.

Coulson A L 1939 Geological report on the alignment of the power pipeline of the Nainital Municipal Board's hydroelectric scheme, Unpublished Report, Geological Survey of India, Lucknow.

Craig H 1961 Isotopic variations in meteoric waters; Science 133(3465) 1702-1703, https://doi.org/10.1126/science. 133.3465.1702.

Dansgaard W 1964 Stable isotopes in precipitation; Tellus 16(4) 436-468.

Deodhar A S, Ansari M A, Sharma S, Jacob N, Kumar U S and Singh G 2014 Isotope techniques for water resources management; BARC News Lett. 337 29-35.

Deshpande R D, Bhattacharya S K, Jani R A and Gupta S K 2003 Distribution of oxygen and hydrogen isotopes in shallow groundwaters from southern India: Influence of a dual monsoon system; J. Hydrol. 271(1) 226-239, https://doi.org/10.1016/S0022-1694(02)00354-2.

Dincer T, Payne B R, Florkowski T, Martinec J and Tongiorgi E G 1970 Snowmelt runoff from measurements of tritium and oxygen-18; Water Resour. Res. 6(1) 110-124, https://doi.org/10.1029/WR006i001p00110.

Drever J I 1988 The geochemistry of natural waters, Englewood Cliffs: Prentice Hall.

Epstein S and Mayeda T K 1953 Variations of the ${ }^{18} \mathrm{O} /{ }^{16} \mathrm{O}$ ratio in natural waters; Geochim. Cosmochim. Acta $\mathbf{5}$ 213-224, https://doi.org/10.1016/0016-7037(53)90051-9.

Froehlich K, Gibson J J and Aggarwal P 2002 Deuterium excess in precipitation and its climatological significance; International Atomic Energy Agency (IAEA); 2002, Report No. IAEA-CSP-13/P.

Gat J R, Bowser C J and Kendall C 1994 The contribution of evaporation from the Great Lakes to the continental atmosphere: Estimate based on stable isotope data; Geophys. Res. Lett. 21(7) 557-560.

Hashimi N H, Pathak M C, Jauhari P, Nair R R, Sharma A K, Bhakuni D S, Bisht M K and Valdiya K S 1983 Bathymetric study of the neotectonic Naini Lake in outer Kumaun Himalaya; Geol. Soc. India 41 91-104.

Johansson S and Dahlin T 1996 Seepage monitoring in an earth embankment dam by repeated resistivity measurements; European J. Eng. Environ. Geophys. 1 229-247.

Karanth K R 1987 Groundwater Assessment, Development and Management, Tata McGraw Hill, New Delhi, India.

Krabbenhoft D P, Bowser C J, Anderson M P and Valley J W 1990 Estimating groundwater exchange with lakes: 
1. The stable isotope mass balance method; Water Resour. Res. 26(10) 2445-2453, https://doi.org/10.1029/ WR026i010p02445.

Kumar B, Nachiappan R, Rai S P, Saravana Kumar U and Navada S V 1999 Improved prediction of life expectancy for a Himalyan Lake: Nainital Lake, UP, India; Mt. Res. Dev. 19(2) 113-121.

Kumar B, Rai S P, Kumar U S, Verma S K, Garg P, Kumar S V, Jaiswal R, Purendra B K, Kumar S R and Pande N G 2010 Isotopic characteristics of Indian precipitation; Water Resour. Res. 46(12) W12548, https://doi.org/10. 1029/2009WR008532.

LaBaugh J W, Winter T C, Rosenberry D O, Schuster P F, Reddy M M and Aiken G R 1997 Hydrological and chemical estimates of the water balance of a closed-basin lake in north central Minnesota; Water Resour. Res. 33(12) 2799-2812, https://doi.org/10.1029/97WR02427.

Li F, Song X, Tang C, Liu C, Yu J and Zhang W 2007 Tracing infiltration and recharge using stable isotope in Taihang Mt., North China; Environ. Geol. 153(3) 687696, https://doi.org/10.1007/s00254-007-0683-0.

Middlemiss C S 1890 Geological sketch of Nainital with some reference on the natural conditions governing mountain slopes; Rec. Geol. Surv. India 21(4) 213-234.

Nachiappan R P, Kumar B and Manickavasagam R M 2002 Estimation of subsurface components in the water balance of Lake Nainital (Kumaun Himalaya, India) using environmental isotopes; Hydrolog. Sci. J. 47(S1) S41-S54.

Payne B R 1983 Interaction of surface water with groundwater; In: Guidebook on Nuclear Techniques in Hydrology, Technical Reports Series. No. 91, International Atomic Energy Agency: Vienna, Austria, pp. 319-324.

Purushothaman P, Mishra S, Das A and Chakrapani G J 2012 Sediment and hydro biogeochemistry of Lake Nainital, Kumaun Himalaya, India; Environ. Earth Sci. 65(3) $775-788$

Rai S P, Kumar B, Kumar S, Garg P and Rawat Y S 2012 Identification of source of leakage in drainage gallery of Tehri dam using isotopic techniques; Hydrol. J. 35(3-4) $63-75$.

Rawat J S 1987 Morphology and morphometry of the Naini lake, Kumaun, Lesser Himalaya; Geol. Soc. India 30(6) 493-498.

Rozanski K, Araguás-Araguás L and Gonfiantini R 1993 Isotopic patterns in modern global precipitation; Climate Change in Continental Isotopic Records 1-36, https://doi. org/10.1029/GM078p0001.

Saini R K, Swain S, Patra A, Khanday G J, Gupta H, Purushothaman P and Chakrapani G J2008 Water chemistry of three Himalayan Lakes: Dal (Jammu \& Kashmir), Khajjiar (Himachal Pradesh) and Nainital (Uttarakhand); Him. Geol. 29(1) 63-72.

Saravana Kumar U, Jacob N, Navada S V, Rao S M, Nachiappan R P, Kumar B and Murthy J S 2001 Environmental isotope study on hydrodynamics of lake Naini, Uttar Pradesh, India; Hydrol. Process. 15(3) 425-439, https:// doi.org/10.1002/hyp.158.

Saravana Kumar U, Sharma S and Navada S V 2008 Recent studies on surface water-groundwater relationships at hydro-projects in India using environmental isotopes; Hydrol. Process. 22(23) 4543-4553, https://doi.org/10. 1002/hyp.7058.

Saravana Kumar U, Sharma S, Navada S V and Deodhar A S 2009 Environmental isotopes investigation on recharge processes and hydrodynamics of the coastal sedimentary aquifers of Tiruvadanai, Tamilnadu State, India; $J$. Hydrol. 364(1) 23-39, https://doi.org/10.1016/j.jhydrol. 2008.10.004.

Singh D, Rai S P, Kumar B, Jain S K and Kumar S 2016 Study of hydro-chemical characteristics of Lake Nainital in response of human interventions, and impact of 20th century climate change; Environ. Earth Sci. 75(20) 1380, https://doi.org/10.1007/s12665-016-6177-1.

Singh S P, Gopal B and Kathuria V 2001 Integrated management of water resources of Lake Nainital and its watershed: An environmental economics approach; EERC, Indira Gandhi Institute for Developmental Research, Mumbai.

Song X, Liu X, Xia J, Yu J and Tang C 2006 A study of interaction between surface water and groundwater using environmental isotope in Huaisha River basin; Sci. China Ser. D 49(12) 1299-1310, https://doi.org/10. 1007/s11430-006-1299-z.

Stewart M K and Morgenstern U 2016 Importance of tritium-based transit times in hydrological systems; Wiley Interdisciplinary Reviews: Water 3(2) 145-154, https:// doi.org/10.1002/wat2.1134.

Valdiya K S 1988 Geology and natural environment of Nainital hills, Kumaun Himalaya; Gyānodaya Prakāshan.

Yao T D, Sun W Z, Pu J C, Tian L D and Jiao K Q 2000 Characteristics of stable isotope in precipitation in the inland area: A case study of the relation between $\delta^{18} \mathrm{O}$ in precipitation and temperature in Urumqi River, China; $J$. Glaciol. Geocryo. 122(1) 15-22.

Yao Z, Liu J, Huang H Q, Song X, Dong X and Liu X 2009 Characteristics of isotope in precipitation, river water and lake water in the Manasarovar basin of Qinghai-Tibet Plateau; Environ. Geol. 57(3) 551-556, https://doi.org/ 10.1007/s00254-008-1324-y. 